\title{
Linkage effects on binding affinity and activation of GPR30 and estrogen receptors $E R \alpha / \beta$ with tridentate pyridin-2-yl hydrazine tricarbonyl-Re/99mTc(I) chelates
}

\author{
Chinnasamy Ramesh ${ }^{1}$, Bj Bryant ${ }^{1}$, Tapan Nayak ${ }^{2,3}$, Chetana M. Revankar ${ }^{3}$, Tamara \\ Anderson $^{2}$, Kathryn E. Carlson ${ }^{5}$, John A. Katzenellenbogen ${ }^{5}$, Larry A. Sklar ${ }^{4}$, Jeffrey P. \\ Norenberg $^{2}$, Eric R. Prossnitz ${ }^{3}$, and Jeffrey B. Arterburn ${ }^{1}$ \\ 1Department of Chemistry and Biochemistry MSC 3C, New Mexico State University, P.O. Box 30001, Las \\ Cruces, NM 88003
}

2Radiopharmaceutical Sciences Program, College of Pharmacy, University of New Mexico Health Sciences Center, Albuquerque, New Mexico 87131

3Department of Cell Biology and Physiology, University of New Mexico, and Cancer Research and Treatment Center, Albuquerque, New Mexico 87131

4Department of Pathology, University of New Mexico, and Cancer Research and Treatment Center, Albuquerque, New Mexico 87131

5Department of Chemistry, University of Illinois, 600 S. Mathews Avenue, Urbana, Illinois 61801

\begin{abstract}
The hormone, 17ß-estradiol (E2), mediates diverse physiological and regulatory control of reproduction, growth, development, immune response, bone mass, neurological, and cardiovascular health. Carcinomas of the breast, endometrium and ovary are common malignancies in female reproductive tissues, and assessment of their estrogen responsiveness is crucial for prognosis and choice of therapeutic regimen. The classical model of estrogen activation describes ligand binding to receptors ER $\alpha / \beta$ initiating conformational changes, which result in interactions with transcriptional coregulators and promoter DNA sequences of target genes. The resulting gene transcription provides a physiological response within hours following estrogen exposure. Additional non-genomic estrogen-induced rapid cell signaling pathways have been recognized as important contributors to the overall biological response. ${ }^{1}$ A new mediator of estrogen-dependent signal transduction, the 7-transmembrane $\mathrm{G}$ proteincoupled receptor GPR30, was recently identified. ${ }^{2}$ This receptor can be co-expressed in cells with $E R \alpha / \beta$, or individually in cells lacking classical estrogen receptors. Revankar et. al demonstrated that GPR30 is an intracellular protein, in the endoplasmic reticulum, that binds estrogen with high affinity $\left(\mathrm{K}_{\mathrm{d}} \sim 6 \mathrm{nM}\right)$ and mediates rapid cellular responses including calcium mobilization and phosphatidylinositol 3,4,5-trisphosphate production in the nucleus. The role of GPR30 in the growth and proliferation of estrogen responsive tumors is a focus of investigation as a new biomarker and target for cancer diagnostics and therapeutics, and could represent an important imaging target in $\mathrm{ER} \alpha / \beta$ negative cells. ${ }^{3}$

Non-invasive imaging technology offers great promise for the in vivo characterization of estrogen-dependent tumors. The intracellular location of ER $\alpha / \beta$ and GPR30 requires neutral, cell permeable imaging agents. Organometallic tricarbonyl $-{ }^{99 \mathrm{~m}} \mathrm{Tc}$ - and ${ }^{94} \mathrm{Tc}-l a b e l e d$ estrogens
\end{abstract}

jarterbu@nmsu.edu.

Supporting Information Available: Experimental and spectral data provided as pdf files, X-ray structure of 2 provided as a cif file. 
have potential for diagnostic imaging using single photon emission computed tomography (SPECT) or positron emission tomography (PET). ${ }^{4}$ Complexes with promising in vitro ER $\alpha /$ $\beta$ receptor binding affinity have been identified, but poor target tissue uptake and complicated radiolabeling procedures have inhibited further development. ${ }^{4}$ Lipophilicity and chelate instability are recognized problems, and other significant parameters may be identified through in vitro characterization of estrogen derivatives in cell culture. Herein, we report a new class of tridentate pyridin-2-yl hydrazine $\mathrm{Re} /{ }^{99 \mathrm{~m}} \mathrm{Tc}$-chelates that exhibit strong binding affinity to GPR30 and ER $\alpha / \beta$, and evaluate intracellular binding with a functional cell-based receptormediated signaling assay.

Alkylation of the di-tboc 5-bromopyridin-2-yl hydrazine ${ }^{4 \mathrm{c}}$ with tbutyl-bromoacetate followed by deprotection with trifluoroacetic acid gave the desired chelate in $90 \%$ yield. This ligand formed the neutral tridentate complex 1 in $87 \%$ yield from tricarbonyl-Re(I) in aqueous ethanol. ${ }^{5}$ Single crystals of 1 suitable for $\mathrm{X}$-ray crystallography were grown by slow evaporation from ethyl acetate. The structure shown in Figure 1 exhibits an undistorted octahedral coordination geometry with tridentate facial orientation of pyridyl, hydrazine-N' and carboxylate groups.

Sonogashira coupling of the protected chelate with $17 \alpha$-ethynylestradiol, followed by deprotection, and $\operatorname{Re}(\mathrm{CO})_{3}{ }^{+}$labeling gave 2 in $95 \%$ yield. The complex was characterized by HPLC-MS ESI-negative detection as two chelate diastereomers (m/z 730, 9.55 and $10.50 \mathrm{~min}$ ) as expected from the facial coordination geometry, but were not isolated separately. Stereospecific hydrogenation of $\mathbf{2}$ using Lindlar's catalyst produced complex $\mathbf{3}$ containing a (Z)-ethene linkage in $70 \%$ yield. Hydrogenation of $\mathbf{2}$ with $\mathrm{Pd} / \mathrm{C}$ gave the saturated alkanelinked complex 4 in $98 \%$ yield.

The receptor binding affinities of 2-4 for full length human ER $\alpha$ and $E R \beta$ were determined by competitive radiometric assays with $\left[{ }^{3} \mathrm{H}\right]$ estradiol and expressed as relative binding affinity (RBA) compared with $17 \beta$-estradiol (100\%). The connecting linkage affected the binding affinity and selectivity of the complexes for ER $\alpha / \beta$. The linear alkyne complex 2 exhibited high affinity and four-fold greater selectivity for ER $\alpha$ over ER $\beta$. The Z-alkene complex $\mathbf{3}$ had greater affinity and two-fold selectivity for ER $\beta$. These RBA values compare favorably with the best examples of reported estradiol tricarbonyl-Re(I) complexes. ${ }^{4}$ Complex 4 had low affinity for both $E R \alpha / \beta$ that can be attributed to unfavorable steric and entropic effects of the flexible alkyl linkage with receptor binding. These results indicate that relatively minor changes in the linkage can affect binding affinity and selectivity, and could be optimized to increase ER subtype selectivity as demonstrated for selective estrogen receptor modulators. 6

The GPR30 binding affinity of $\mathbf{2}$ and $\mathbf{3}$ was determined using a fluorescent Alexa633-labeled conjugate of estradiol that binds to GPR 30 and ER $\alpha / \beta .^{2 \mathrm{c}}$ Binding affinity was assessed by flow cytometry using GPR30-transfected COS7 cells that do not express endogenous GPR30 or $\mathrm{ER} \alpha / \beta$. The cells were permeabilized with saponin to enable access of the charged fluorescent estrogen. Competitive binding was evaluated using $17 \beta$-estradiol as a positive control for specific binding of the fluorescent estrogen to GPR30 Fig 2a, and the relative Ki values of 2 and $\mathbf{3}$ are reported in Table 1. The non-binding diastereomer 17 $\alpha$-estradiol was included as a negative control. Both complexes $\mathbf{2}$ and $\mathbf{3}$ exhibited strong binding to GPR 30 and demonstrate the potential for targeting this receptor.

To assess receptor binding in whole cells we employed a functional assay based on the rapid receptor-mediated mobilization of intracellular calcium elicited by estrogen ligand binding to ER $\alpha$ and GPR30. Transfected COS7 cells expressing ER $\alpha$ or GPR30 were incubated at room temperature with the calcium-responsive fluorescent dye indo1-AM. Dose-dependent fluorescence was measured at 10,100, and $1000 \mathrm{nM}$ extracellular concentrations of E2, 2 and 3 (Figure 2b). Alkyne complex 2 initiated a rapid increase in intracellular calcium 
concentrations with both ER $\alpha$ and GPR30. The Z-alkene complex $\mathbf{3}$ produced lower calcium levels during the same time period. These results demonstrate that complexes $\mathbf{2}$ and $\mathbf{3}$ are able to penetrate the cell membrane, bind and activate the targeted estrogen receptors. Cell permeability, a critical parameter affecting the kinetics of tissue uptake and overall biodistribution, can be assessed using this type of functional assay.

Convenient methodology for labeling with $\left.\left[{ }^{99 \mathrm{~m}} \mathrm{Tc}(\mathrm{CO})_{3}\left(\mathrm{H}_{2} \mathrm{O}\right)_{3}\right)\right]^{+}$has been developed, and the IsoLink ${ }^{\circledR}$ kit from Mallinckrodt reliably produced the aquo complex with radiochemical purity $\geq 98 \%(n \geq 20) .{ }^{7}$ Due to the acid sensitivity of the tertiary propargylic $17-\beta$-alcohol of the estradiol chelate, the alkaline mixture was neutralized with acetic acid rather than $\mathrm{HCl} .{ }^{99 \mathrm{~m}} \mathrm{Tc}-$ labeling was conducted at ambient temperature for $2 \mathrm{hr}$. Solid phase extraction using a C-18 Sep-Pak ${ }^{\circledR}$ with $40 \% \mathrm{EtOH} / \mathrm{H}_{2} \mathrm{O}$ effectively removed excess ligand, and the ${ }^{99 \mathrm{~m}} \mathrm{Tc}$-complex 2 eluted with EtOH in radiochemical yields ranging from $90-95 \%$ of the total loaded radioactivity. The radiochemical purity assessed by HPLC was $\geq 85 \%(\mathrm{n} \geq 10)$, and chromatographic resolution of the two diastereoisomeric chelates was observed by radiometric detection. The specific activity determined post-purification was $40 \mathrm{mCi} / \mu \mathrm{g}$. HPLC and ITLC analyses demonstrated no significant degradation, reoxidation or "leak" of ${ }^{99 \mathrm{~m}} \mathrm{Tc}$ from the chelate after 48 hours of storage at $4{ }^{\circ} \mathrm{C}, 25^{\circ} \mathrm{C}$ and $37^{\circ} \mathrm{C}$. The complex exhibited a $\log \mathrm{P}$ octanol/water coefficient of $3.87 \pm 0.49(\mathrm{n}=4)$ determined by shake flask method, that corresponds closely with estradiol $\log \mathrm{P}^{o / w}=4.01$. The stability of ${ }^{99 \mathrm{~m}} \mathrm{Tc}-2$ was also evaluated in the presence of an 100-fold excess of histidine $(1 \mathrm{mM})$. The radiochemical purity accessed via HPLC after $24 \mathrm{hr}$ incubation at $37^{\circ} \mathrm{C}$ was $76.32 \% \pm 2.81(\mathrm{n}=3)$ with less than $1 \%$ reoxidation of the ${ }^{99 \mathrm{~m}} \mathrm{Tc}$ species.

These results demonstrate that chelates $\mathbf{2}$ and $\mathbf{3}$ interact with receptors GPR 30 and ER $\alpha / \beta$ in whole cells, and suggests increased use of in vitro assays may facilitate the development of targeted imaging agents for intracellular receptors.

\section{Supplementary Material}

Refer to Web version on PubMed Central for supplementary material.

\section{ACKNOWLEDGMENT}

NIH/SCORE GM08136 (J.B.A.), CA116662 and UNM CRTC Translational Research Award (E. R. P.), CA25836 (J. A. K.), Cowboys for Cancer Research Foundation. WM Keck Foundation and NIH Roadmap U54MH074425.

\section{References}

1. a Losel RM, Falkenstein E, Feuring M, Schultz A, Tillmann H-C, Rossol-Haseroth K, Wehling M. Physiol. Rev 2003;83:965-1016. [PubMed: 12843413] b Osborne CK, Schiff R. J. Clin. Oncol 2005;23:1616-1622. [PubMed: 15755967] c Ariazi EA, Ariazi JL, Cordera F, Jordan VC. Curr. Top. Med. Chem 2006;6:181-202. [PubMed: 16515478]

2. a Filardo EJ, Quinn JA, Bland KI, Frackelton AR. Mol. Endocrin 2000;14:1649-1660. b Thomas P, Pang Y, Filardo EJ, Dong J. Endocrinology 2005;146:624-632. [PubMed: 15539556] c Revankar CM, Cimino DF, Sklar LA, Arterburn JB, Prossnitz ER. Science 2005;307:1625-1630. [PubMed: 15705806]

3. Prossnitz ER, Arterburn JB, Edwards BS, Sklar LA, Oprea TI. Expert Opin. Drug Discov 2006;1:137150.

4. a Top S, El Hafa H, Vessieres A, Quivy J, Vaissermann J, Hughes DW, Mcglinchey MJ, Mornon JP, Thoreau E, Jaouen G. J. Am. Chem. Soc 1995;117:8372-8380. b Luyt LG, Bigott HM, Welch MJ, Katzenellenbogen JA. Biorg. Med. Chem. Lett 2003;11:4977-4989. c Arterburn JB, Corona C, Rao KV. J. Org. Chem 2003;68:7063-7070. [PubMed: 12946150] d Top S, Boubekeur L, Jaouen G, 
Mundwiler S, Spingler B, Alberto R. Eur. J. Inorg. Chem 2004:2013-2017. e Bigott HM, Parent E, Luyt LG, Katzenellenbogen JA, Welch MJ. Bioconjugate Chem 2005;16:255-264.

5. Lazarova N, James S, Babich J, Zubieta J. Inorg. Chem. Commun 2004;7:1023-1026.

6. Manas ES, et al. J. Am. Chem. Soc 2004;126:15106-15119. [PubMed: 15548008]

7. a Alberto R, Schibli R, Egli A, Schubiger AP. J. Am. Chem. Soc 1998;120:7987-7988. b Schibli R, Schubiger PA. Eur J Nucl Med Mol Imaging 2002;29:1529-1542. [PubMed: 12397472] c

Stichelberger A, Waibel R, Dumas C, Schubiger PA, Schibli R. Nucl. Med. Biol 2005;30:465-470. [PubMed: 12831983] 


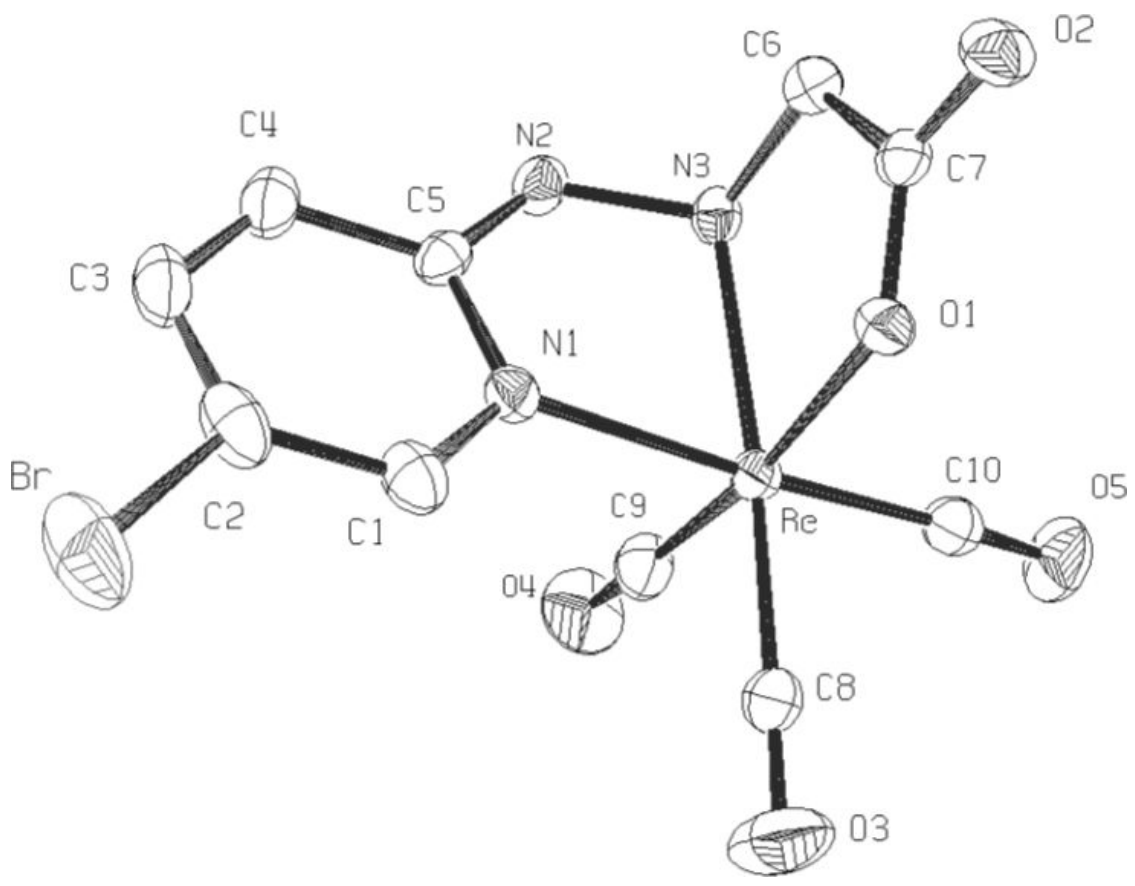

Figure 1.

X-ray ORTEP rendition of complex 1 
a)

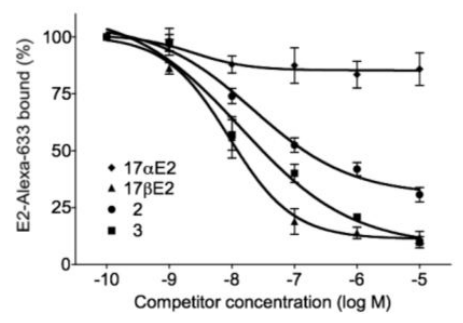

b)

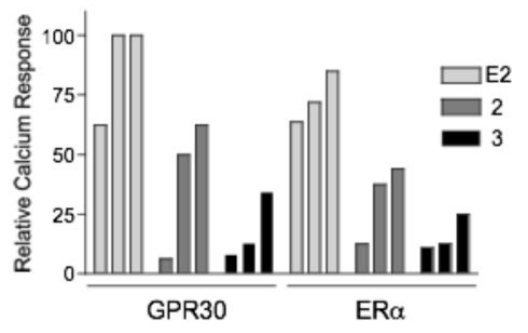

Fig 2.

Fluorescence assays for GPR30 binding and activation with 2 and 3. a) GPR30 competitive binding of E2, 17 $\alpha-\mathrm{E} 2, \mathbf{2}$, and $\mathbf{3}$ with fluorescent estradiol derivative E2Alexa using permeabilized COS7 cells. b) Calcium mobilization assay for GPR30 and ER $\alpha$ in transfected COS7 cells vs concentration of E2, and complexes $\mathbf{2}$ and $\mathbf{3}$ (each at 10, 100, and $1000 \mathrm{nM}$ ). 
Table 1

Structure and relative binding affinity of estradiol complexes $2,3,4$ for ER $\alpha / \beta$ and GPR30<smiles></smiles><smiles>[CH2-]CC#CC=CCC#CC</smiles>

$\mathrm{ER} \alpha$ ER $\beta$ GPR30
20

5 42
10

24

64
0.5 N.D. 